\title{
Creativity, entrepreneurship and economic development: city-level evidence on creativity spillover of entrepreneurship
}

Article

Accepted Version

Belitski, M. and Desai, S. (2016) Creativity, entrepreneurship and economic development: city-level evidence on creativity spillover of entrepreneurship. Journal of Technology Transfer, 41 (6). pp. 1354-1376. ISSN 1573-7047 doi:

https://doi.org/10.1007/s10961-015-9446-3 Available at https://centaur.reading.ac.uk/54798/

It is advisable to refer to the publisher's version if you intend to cite from the work. See Guidance on citing.

To link to this article DOI: http://dx.doi.org/10.1007/s10961-015-9446-3

Publisher: Springer

All outputs in CentAUR are protected by Intellectual Property Rights law, including copyright law. Copyright and IPR is retained by the creators or other copyright holders. Terms and conditions for use of this material are defined in the End User Agreement.

www.reading.ac.uk/centaur 
Central Archive at the University of Reading

Reading's research outputs online 
CREATIVITY SPILLOVER OF ENTREPRENEURSHIP: AN EMPIRICAL STUDY OF CREATIVITY, ENTREPRENEURSHIP AND URBAN ECONOMIC DEVELOPMENT

\author{
Maksim Belitski * \\ Henley Business School \\ University of Reading \\ Email: $\underline{\text { m.belitski@ reading.ac.uk }}$ \\ Sameeksha Desai \\ School of Public and Environmental Affairs \\ Indiana University \\ Email: desai@indiana.edu
}

\begin{abstract}
We examine the black box of creativity, entrepreneurship and economic development by asking about the mechanisms through which creativity can influence economic development in cities. We propose that, like the knowledge spillover theory of entrepreneurship, creativity spillovers occur and can be slowed by a creativity filter. We examine how creativity and entrepreneurship, and creativity and a melting pot environment, interact to influence urban economic development. Using data on 187 cities in 15 European countries for the period 1999-2009, we advance the extant literature by providing evidence on the existence and dynamics of a creativity filter.
\end{abstract}

Keywords: creativity, spillover, entrepreneurship, melting pot, economic development, urban 


\section{Introduction}

Creativity and ideas are key components in enhancing the performance of organizations (Drazin, Glynn and Kazanijan, 1999; Shalley, Gilson and Blum, 2000; Shalley, Zhou and Oldham, 2004; Fleming and Marx, 2006; Somech and Drach-Zahavy, 2013) and regions (Lucas, 1988; Rodríguez-Pose and Vilalta-Bufî 2005; Acs and Armington, 2006; Audretsch and Keilbach, 2007; Marrocu and Paci, 2012). Despite several studies which examine the relationship between human capital, creativity and regional economic development (e.g., Boschma and Fritsch, 2009; Markusen, 2006; Marrocu and Paci, 2012), relatively little attention has been paid to the mechanisms that induce these effects and in particular, at the subregional level, such as the city (Audretsch et al., 2015). An important question concerns how creativity can be facilitated and harnessed for greater urban economic development (Boschma and Fritsch, 2009; Lorenzen and Andersen, 2009; Falck, Fritsch and Heblich 2011).

Several streams of inquiry are relevant in answering this question. Ongoing research on creativity and entrepreneurship in the last 10-15 years has examined individuals and teams (Cohen and Bailey, 1997; Gilson and Shalley, 2004; Shalley et al., 2004; Fleming et. al., 2007; ), firms (Choi, Anderson and Veillette, 2009; Somech and Drach-Zahavy, 2013) or regions and countries (Fleming and Marx, 2006; Boschma and Fritsch, 2009; Lorenzen and Andersen, 2009). While these studies have advanced our understanding of the relationship between creativity and entrepreneurship, the conduit from creativity to economic growth remains an open question (Audretsch and Belitski, 2013).

A second important stream of inquiry is on knowledge spillovers, found to be greater in regions with higher population density, industrial density and cultural diversity (Audretsch et al., 2010), indicating exploitation of competitive advantage of urban areas (Brunello and De Paola, 2004; Audretsch and Lehmann, 2005; Agarwal et al., 2007, 2010). Recent studies 
on creativity and knowledge spillovers of entrepreneurship (Audretsch and Keilbach, 2007; Acs et al., 2009; Agarwal et al., 2010; Marrocu and Paci, 2012) have not yet produced consensus on how geography and entrepreneurship can influence knowledge flows and effects on urban economic development; and how region-specific characteristics of human capital need to be taken into account (Qian et al., 2012). Some of these studies consider the firm level, examining the generation of creativity in groups and organizations, and how this influences economic performance (Gilson and Shalley, 2004; George, 2007; Somech and Drach-Zahavy, 2013), and others examine the contexts for human and creativity in varied business environments (Rodríguez-Pose and Vilalta-Bufì 2005; Acs and Armington, 2006; Audretsch, Keilbach and Lehmann, 2006; Florida et al., 2008; Agarwal et al., 2010).

These streams of prior research point to the role for creativity in entrepreneurship, as well as in contributing to economic performance. However, our study focuses on a significant gap which still exists, on the mechanisms of creativity commercialization for urban economic development (Audretsch and Keilbach, 2007; Acs et al., 2009; Boschma and Fritsch, 2009; Asheim and Hansen, 2009). In addressing this gap, we bridge the literature on knowledge spillover theory of entrepreneurship and the literature on creativity and entrepreneurship.

We make four contributions to the existing literature. First, we treat creativity as heterogeneous and as "a different measure of human capital - the 'creative class', based on the actual occupations of individuals in specific jobs" (Marrocu and Paci, 2012: 369). In doing so, we draw upon the heterogeneity of creativity (Lee, Florida and Acs, 2004; Markusen, 2006; Asheim and Hansen, 2009; Lorenzen and Andersen, 2009; Florida and Mellander, 2010 and Marrocu and Paci, 2012). This goes beyond extant studies linking entrepreneurship and creativity, which treat creativity as homogeneous (Amabile, 1996; Choi et al., 2009; Fleming and Marx, 2006). Second, we provide empirical evidence that industry mix does not per se contribute to urban economic development, as long as what people know 
and create is recognised and exploited through starting a new business (Audretsch et al., 2006, 2008; Qian et al., 2012). Third, we demonstrate through interaction analysis the role of entrepreneurship in moderating the relationship between creativity embedded in a specific industrial sectors and urban economic development. Our approach suggests this could be a missing link with important implications for organizational and urban competitiveness. Fourth, we introduce the concept of a creativity filter as a gap between commercialized and uncommercialized creativity. We also find that cities rich in openness, talent and diversity are associated with a higher regional development.

Building upon the knowledge spillover theory of entrepreneurship (Acs et. al., 2009; Audretsch and Keilbach, 2007; Agarwal et al., 2010) and studies of creativity and entrepreneurship in "places" (Florida, 2002; Boschma and Fritsch, 2009; Asheim and Hansen, 2009; Marrocu and Paci, 2012), we demonstrate that entrepreneurship serves as a conduit for the spillover of knowledge and creativity to urban economic development.

The remainder of the paper is as follows. In the next section, we discuss our theoretical background and our hypotheses. We present our data and method in the third section, and report our results in the fourth section. We discuss our findings in section five, followed by a brief conclusion.

\section{Theoretical Background and Hypotheses}

\subsection{The notion of creativity}

The concept of creativity is difficult to capture and measure, yet continues to gain importance and meaning to organizations and to policymakers. Creativity in the 1990s was linked as an outcome to the production of new ideas and marketable innovation (e.g., Amabile, 1996; Oldham and Cummings, 1996; Drazin et al., 1999). A series of studies on creativity and entrepreneurship since the late 1990s (Cohen and Bailey, 1997; Fleming and 
Marx, 2006; Boschma and Fritsch, 2009; Marrocu and Paci, 2012) argued that creative activity can improve individual, firm and cluster performance.

Florida (2002) identified creativity as the process of introducing and implementing new ideas which are critically processed such that other ideas seem useless or trivial. Creativity is embodied in an individual who adds economic value of a firm (Florida, 2002). A management perspective on creativity (Drazin et al., 1999) is more tangible and treats it as the ability to focus on and identify complex problems, formulate propositions and make inferences from hypotheses, discuss ideas with others through socialization and networking, and even contradict normal expectations. Consequently, creative people can choose to engage (or not) in a creative process and to transfer (or not) creative ideas into marketable products (Kahn, 1990). Problem identification and linking new ideas can be benefits from creative activity, not simply just product creation (Gilson and Shalley, 2004).

While some studies on performance outcomes treat creativity as homogeneous (Shalley et al., 2004; Choi et. al., 2009; Somech and Drach-Zahavy, 2013), the literature on creativity and entrepreneurship tends to consider creativity as a heterogeneous concept (Lee et al. 2004; Florida 2002; Boschma and Fritsch, 2009; Florida and Mellander, 2010; Falck et al., 2011). Building on entrepreneurship and creativity literature we consider creativity as the individual's ability to introduce and implement new ideas and new work style, which can differ across various industries, known as creative industries (Boschma and Fritsch, 2009). Creativity embedded in an individual or industry (Florida, 2002) is therefore heterogeneous because it can vary based on profession and industry, not necessarily qualifications, and is diffused through the professional activity of an individual. Though members of the creative class may be found in every industry, it is useful to distinguish workers employed in sectors where performing creative tasks is secondary, from workers employed in sectors where it is primary. It is also useful to distinguish creativity from human capital, because what people do 
may be different from what they know (Marlet and van Woerkens, 2004). Human capital is considered and measured as some type of formal educational attainment, such as the proportion of population with university or college degree (Glaeser, 2004; Qian et al., 2012). It is important to recognize that human capital and creativity are not the same (Florida et al. 2008; Boschma and Fritsch, 2009).

\subsection{Creativity, economic development, and entrepreneurship}

Although a positive impact of creativity on urban economic development is almost intuitive (Florida 2002, 2012; Markusen, 2006; Agarwal et al., 2010), the mechanisms which act as a conduit of creativity to entrepreneurship remain subtle. This is at least for three main reasons. First, unlike knowledge (Arrow, 1962; Acs et al., 2009), creativity is distinct from traditional resources because of excludability and non-transferability. Creativity is impossible to transfer to other individuals because of the skill, experience, talent, work and lifestyle of the individual. This is unlike formal education, such as specialized degree programs, which can more reasonably be compared. As opposed to human capital and knowledge, creativity could be excluded from accessing and using creative ideas, skills and talent by a third party, as this capital is in an individual's head. The use of creative skills and new ideas by an individual (unlike the use of knowledge clustered within an organization, industry or a city) does preclude others from copying creativity.

Second, outcomes associated with new, non-trivial ideas generated by the creative class are highly uncertain (Florida, 2002). Creative individuals will be affected by uncertainty related to bringing their creative ideas into the market and turning those ideas into profitable, sustainable business activity.

Third, a climate conducive to creativity is critical for individuals to engage in creative problem-solving. Creativity (unlike human capital and information) can only be transmitted 
when members of a group feel comfortable in jointly taking risks, resolving uncertainty and finding new ways of problem-solving. The environment in which the creative class works should be perceived as non-threatening, tolerant and open to different ideas and cultures (West, 1990; Florida, 2002). Creative individuals need to feel comfortable taking risks in a non-threatening environment, conducive to new ideas (Gilson and Shalley, 2004; Shalley et al., 2004). Such an environment could include collaborative networks which influence creativity (Fleming and Marx, 2006) and could create a supportive and conducive environment to test new ideas. An environment filled with new ideas, alternative solutions, collaborative networks and cultural diversity is known as a melting pot environment (Lee et. al., 2004; Bassett-Jones, 2005; Boschma and Fritsch, 2009) and, conditional on the level of creativity, can enhance economic development in cities. The role of diversity and cosmopolitanism can be especially important (Audretsch et al., 2010; Florida, 2012). We therefore hypothesize:

\section{H1a: More creativity is associated with higher urban economic development.}

H1b: A combination of creativity and a melting pot environment is associated with

\section{higher urban economic development.}

A related question is what affects the propensity of creativity to spill over. Audretsch and Keilbach argue that that (unlike investment in physical capital), investments in knowledge are more likely to spill over for commercialization by third-party firms who have not incurred the full costs associated with implementing ideas developed from the knowledge (2007: 1246). Entrepreneurship, such as in the form of newly established firms, can also serve as a conduit of knowledge in an economy (Audretsch and Lehmann, 2005; Audretsch et al., 2008; Acs et al., 2009; Zahra and Wright, 2011) and impact economic development by channeling other resources, such as creativity. However, the possible mechanism of creativity spillover - in other words, a conduit which enables introducing outcomes of creative ideas to 
the market - remains a black box. Since creativity promotes idea generation but the implementation of those ideas is limited due to things like non-transferability and idea uniqueness, creativity could affect economic development indirectly via entrepreneurship. Specifically, an interaction analysis allows us to consider an effect of creativity on economic development conditional on entrepreneurship in a city (Audretsch et al., 2015).

Our creativity spillover of entrepreneurship approach clarifies where (melting pot environment) and why (higher entrepreneurship) creativity may positively contribute to entrepreneurship, innovation and growth in firms, industries and cities. Our creativity spillover of entrepreneurship approach adds to the growing literature on the knowledge spillover of entrepreneurship (Audretsch and Keilbach, 2007; Acs et al., 2009) and to research on entrepreneurship and creativity (e.g., Gilson and Shalley, 2004; Somech and Drach-Zahavy ,2013), and states that entrepreneurship may tap into creative melting pot environments to produce more outputs. Creativity is embodied in individuals and industries (Stein, 1974; Markusen, 2006), which Florida (2002) posits as "creative classes" across various sectors that can drive change and commercialize the outcomes of entrepreneurship. We consider entrepreneurial activity serves as a conduit of creativity to high growth (Agarwal et al., 2010). Unlike other models, such as input-process-output models, creativity needs to be brought to the market by a third party (entrepreneur) which performs the role of a conduit for the path from creativity to marketing new ideas. We thus hypothesize:

\section{H2a: Entrepreneurship moderates the relationship between creativity and urban economic development (creativity spillover of entrepreneurship).}

Entrepreneurs have been found to facilitate commercialization of ideas (Acs et al., 2009; Qian et al., 2012). Creativity that could be commercialized, but is not, creates a potential gap in creativity diffusion. We refer to this as a creativity filter. The larger the gap between the ideas embodied in the creative class and the actual commercialization of ideas, 
then the larger the creativity filter. It can be also explained as a creativity gap, e.g. the difference between the potential of creativity commercialisation and a factual commercialisation of creativity. Unlike the knowledge filter, which was described by Audretsch and Keilbach (2007: 1247) as "inertia inherent in decision-making under uncertainty within incumbent organizations", the creativity filter is about the inertia inherent in decision-making of entrepreneurs under uncertainty. It is a combination of an individual ready to recognize the opportunity and be creative to push it further in the market (Audretsch and Belitski, 2013). We hypothesise:

\section{H2b: The size of the creativity filter will be larger with less entrepreneurship}

Along with entrepreneurship, melting pot environments perceived as comfortable and nonthreatening for creativity diffusion will minimize the volume of creativity which does not get commercialized. An individual may choose not to share creative ideas, should the benefits be uncertain and the environment unfriendly (Gilson and Shalley, 2004). The knowledge base can influence living and business climate in terms of attracting and retaining talent (Asheim and Hansen, 2009).

The presence of a melting pot environment which offers tolerance and diversity (Florida, 2002; Audretsch et al., 2010) is conducive to economic development. This kind of environment is appreciated by the creative class, creating more space for people who do not fit with common norms to leverage new ideas and creativity (Florida, 2012). This increases opportunities for innovative thinking and development of new competitive knowledge, and raises the chances of more well-educated and entrepreneurial people moving and starting business in a city, bringing regional change (Glaeser et al., 2010, 2014) Entrepreneurs attracted to amenities and diversity (Florida, 2002) will commercialize knowledge (Acs et al., 
2009) and find new combinations (Agarwal et al., 2010). Similarly, a non-melting pot environment should hinder commercialization of creative ideas. We thus hypothesize:

\section{H3: A melting pot environment is associated with higher urban economic}

\section{development.}

The entire mechanism of the creativity spillover of entrepreneurship is shown in Figure 1.

\section{Method}

\subsection{Data}

Methodologically, cities are the most appropriate spatial units to fully understand the process of creativity commercialization (Florida, 2002; Audretsch et al., 2015). Our study follows the Eurostat classification of a core city, also known as the local administrative unit (LAU), corresponding to administrative boundaries of the city (European Commission, 2010). The advantage of using LAUs is an emphasis on knowledge spillovers, which can occur within a certain area $^{1}$ (Audretsch and Feldman, 1996; Peri, 2005; Acs and Armington, 2006; Audretsch et al., 2006), as well as managerial concerns and responsibility when designing policies for cities.

We use the European Urban Audit Surveys (UAS) from Eurostat (2012). UAS is a comprehensive dataset of socio-economic, business, environment, entrepreneurship, national composition and education indicators. Our cross-sectional dataset includes 187 cities in 15 European countries for the period 1999-2009 (see Table 1 and Figure 2). The data is a three period short panel. The dataset includes $153(81 \%)$ cities in Western Europe and 33 (19\%) cities in Eastern Europe. The sample includes cities with at least 50,000 residents.

\footnotetext{
${ }^{1}$ It is important to note that economic activity may cross core-city boundaries. For example, the "total population" indicator provides the amount of people living within the city, but does not include surrounding communities outside the core city. Therefore a question may arise over whether the surrounding agglomeration zone potentially effects urban economic development within larger urban areas. Later in the paper, we report on a robustness check which we implement in light of the overlap of economic activity between the LAU and large urban zones (LUZ). Leveraging this effect ties to the concept of market potential (Harris, 1954).
} 
Due to missing values in the data, once all variables are included, we are left with 240 observations (on average, 1.4 observations per city). Another factor worth noting is the distribution of data within time periods: 81 of the city observations were available from 19992002, 172 from 2003-2006 and 139 from 2007-2009. While included all variables the number of observations with non-missing values has dropped to 240 . Note that the market potential indicator was not taken directly from Eurostat but was designed for a robustness check. Variables and summary statistics are shown in Table 2. A correlation matrix is shown in Table 3.

\subsection{Variables and controls}

\section{Dependent variable}

Our dependent variable, urban economic development, is measured as GDP per capita in PPP (in Euro) taken in logarithms. This measure has been used in the established literature for studies of countries and regions (Glaeser et al., 2010; Audretsch et al., 2006, 2010). The UAS is relatively new and our study is among the first to use this across cities.

\section{Explanatory variables}

Our first variable of explanatory interest is creativity (Stein, 1974; Amabile, 1996). We measure creativity with consideration of industry (Audretsch et al., 2002; Boschma and Fritsch, 2009), using aggregated sectors classified by $\mathrm{NACE}^{2}$ and identifying creativity as a proportion of employment in those sectors. We use the following sectors: Culture, High-Tech manufacturing, Trade and hospitality, Finance, Public, Communication and ICT. We do not include the agriculture, fishing and forestry sector, which becomes a reference category. The proportion employed in culture and entertainment is a proxy for creativity in the Culture

\footnotetext{
${ }^{2}$ NACE - General Name for Economic Activities in the European Union, and is the European standard for industry classifications, introduced in 1970.
} 
sector $^{3}$, the proportion employed in high-tech manufacturing is a proxy for creativity in the high-tech manufacturing sector, and likewise for each of the remaining Trade and hospitality, Finance, Public, Communication and ICT sectors. Our reasoning behind consideration of "industry mix" (Audretsch and Feldman, 1996; Audretsch et al., 2002) is that, in addition to industry-specific characteristics which could themselves be more or less attractive to creative individuals, "certain occupations are more important than others when it comes to entrepreneurship (Florida, 2012)". This could be the case when some job tasks are creative in nature, such as in ICT or trade and hospitality (Lee et al., 2004; Boschma and Fritsch, 2009). Also, this could be the case in industries where basic business skills are part of the industry and in industries where market knowledge may be important to industry activity, such as in media, design and entertainment, high-tech manufacturing and ICT (Florida, 2012).

Our second explanatory variable captures diversity and tolerance in a city (Florida, 2002). To do this, we measure the melting pot index as the population comprising nonEuropean Economic Area (EEA) nationals, which captures diversity, tolerance and openness to new ideas (Florida 2002, 2012; Lee et. al., 2004).

Our third explanatory variable is entrepreneurship, measured as a proportion of new business start-ups to existing companies registered in a city (see Praag and Versloot, 2007; Zahra and Wright, 2011). New business start-up refers to enterprise births ${ }^{4}$ in a city; an existing company moving in is regarded as new (Eurostat, 2012). The proportion of new start-ups as a dynamic measure of entrepreneurship is robust (Shane and Venkataraman, 2000) and has two advantages. First, it is an established proxy for the intensity of entrepreneurial activity in a city (Glaeser et al., 2010). Second, it is available for a large

\footnotetext{
${ }^{3}$ This is also known as Bohemians in studies following Florida (2002).

${ }^{4}$ Excluding mergers, break-ups, split-offs, restructuring of enterprises, changes of company activity or name.
} 
number of cities, and after applying appropriate harmonization by Eurostat, it can be compared across cities and over time (Eurostat, 2012) . $^{5}$

\section{Control variables}

We use a measure of education attainment to control for human capital (Glaser, 2004; Audretsch et al., 2006; Glaeser et al., 2010): Proportion of residents with tertiary education (ISCED $\left.{ }^{6} 5-6\right)$. The relevance of human capital in urban economic development has been established in recent research (Audretsch and Keilbach, 2007; Rodríguez-Pose and VilaltaBufi, 2005) and it is appropriate to include this control in our study to distinguish what people do from what they know.

We also control for economies of scope and scale, using a population density for a market size (Boschma and Fritsch, 2009; Falck et. al., 2011; Acs et al., 2014). In addition we control for the difference in market size potentialbetween a core city and larger urban area based on the "market potential" approach (Harris 1954). This measure is calculated as the ratio of local administrative unit population density (LAU) to larger urban zone population densitydescribed in details in section5 (robustness check).

We control for the presence of country fixed effects as a robustness check, the impact of institutions, culture and other unobserved heterogeneity across countries by including country dummies (Baumol 1993; Audretsch and Belitski, 2013). The results have not changed. F-test that all coefficients of country dummies are jointly equal to zero was rejected at $1 \%$ significance level. In addition, we clustered our standard errors by country. This allows correlation of standard errors within the country, but not across the countries.

\footnotetext{
${ }^{5}$ A limitation of this measure is it does not capture firm survival. However, we want to study entrepreneurship as a conduit of creativity, allowing for the transfer of new ideas into marketable innovation; therefore, capturing new businesses which reflect the initial stage of commercialization is adequate for our purposes.

${ }^{6}$ UNESCO International Standard Classification of Education (ISCED) facilitates comparisons of education statistics. Tertiary education comprises ISCED levels 5, 6, 7 and 8, which are labelled as short-cycle tertiary, bachelor or equivalent, master or equivalent and doctoral or equivalent, respectively.
} 


\subsection{Empirical strategy}

Endogeneity issues

Potential criticisms of our approach include endogeneity, multicollinearity and nonlinearities. The relationship between creativity and economic performance could be bidirectional (Boschma and Fritsch 2009; Falck et al., 2011). The Culture sector has been found to support local quality of life, build social capital, encourage tourism and attract jobs (Florida, 2002). At the same time, the most successful and wealthy European cities have vibrant cultural and distinctive melting pot environments, rich in cultural amenities with skilled and talented people (Eurostat, 2012). The endogeneity issue could also arise because individuals with high human capital may be willing and able to pay for cultural services, bridging the bi-directional relationship between human capital and creativity. Factors like lifestyle amenities, culture, social capital and quality of life may affect both human capital and creativity. We deal with the bi-directional relationship between human capital and creativity by including both variables on the right hand side of the model and therefore, the effect of human capital on urban economic development is now explicitly controlled.

Further, the relationship between the dependent variable and the explanatory variables which proxy creativity is not linear, as we cannot assume constant marginal returns to creativity. We use the logarithm of GDP per capita to account for a non-linear relationship.

We estimate a pooled OLS data model ${ }^{7}$, with each city observed between one and two times over 1999-2009. This limited the potential use of the panel data model like fixed effects of random effects. We control for country-specific characteristics by including country fixed effects in several specifications, as a robustness check. We also control for time fixed effects by including time period dummies in the estimation. The time period 2004-2009 is a reference period when controlling for time fixed effects. F-test for the joint significance of

\footnotetext{
${ }^{7}$ Pooled OLS allows improvements in efficiency over a simple average approach by year cross-section as it pools all available data over three time periods.
} 
time-fixed effects and country controls were implemented. We consider the following linear panel regression model which resembles the Cobb-Douglas production function at a regional level (Douglas 1976):

$$
Y_{i t}=\alpha_{i}+d_{t}+\beta_{1 i} x_{i t}+\beta_{2 i} \dot{x}_{i t}+\mu_{i t}
$$

where $i=1, \ldots ., \mathrm{N} ; t=1, \ldots ., \mathrm{T}$; where $Y_{i t}$ indicates GDP per capita in PPP of a city $i$ at time $t$, $x_{i t}$ is a $k \times 1$ set of explanatory regressors including new firm start-ups, melting pot and sector specialization as a proxy for creativity; $\dot{x}_{i t}$ is a $k \times 1$ set of control variables (e.g. human capital, country dummies, population density); $\alpha_{i}$ is a city- specific intercept, $d_{t}$ is

time control, and $\mu_{i t}$ is the idiosyncratic error term. All variables in (1) are expressed in logarithms, except for those expressed in percentages or proportions. Heteroskedasticity robust standard errors clustered by country are included. This allows correlation of standard errors within the country, but not across the countries.

We run our analysis on a dataset comprising 240 observations across 187 cities. Our results for the analysis with entrepreneurship in Table 4, and for the analysis with the melting pot index in Table 5. In both sets of tables, Models 5-10 include interaction terms of entrepreneurship and proportion of employed by sector in a city.

\section{Results}

Our interaction analysis methodology (Preacher et al., 2007) is reported in Tables 4 and 5. Table 4 presents results on creativity and the moderating effect of entrepreneurship on urban economic development. Table 5 presents results on creativity and the moderating effect of melting pot environment on urban economic development. 
We first report results for our controls. Human capital is found positive and statistically significant for urban economic development. The coefficient for human capital does not change but significance varies slightly in Models 2-3 $(0.01, \mathrm{p}<0.1)$ and Models 4-11 (0.01, $\mathrm{p}<0.05)$ in Table 4. It also remains positive and statistically significant, with unchanging coefficient, across Models 2-11 $(0.01, \mathrm{p}<0.5)$ in Table 5. The findings for human capital are consistent with previous research (Glaeser, 2004; Audretsch et al., 2008; Glaeser et al., 2014). Tertiary education especially has been found positively related to economic development (Sianesi and Van Reenen 2003; Audretsch and Keilbach, 2007; Audretsch et al., 2008). The control for market size potential is not significant across any of the models in Tables 4 and 5, indicating that the existence of a potential market by itself does not have positive or negative implications for urban economic development. Finally, country fixed effects point to cultural and institutional differences between countries included in this study, and that on average higher GDP per capita in Belgium, Cyprus, Germany, Spain, Finland, France, Netherlands, Sweden and Slovenia ${ }^{8}$.

We now turn to our hypotheses. A link between creativity and urban economic development is established, shown in Models 2-3 in both the Tables 4 and 5. These findings support H1a, and are in line with the idea of a "creative class city" (Florida, 2002; Florida et al., 2008). Further, more diverse cities are also likely to have higher GDP per capita. We now turn to our results when examining if the combination of creativity and a melting pot environment will result in higher economic development, as predicted in $\mathrm{H} 1 \mathrm{~b}$. As indicated in Models 5-10 in Table 5, H1b was not supported. Interestingly, although the interaction of ICT sector with melting pot index is positive and statistically significant $(0.01, \mathrm{p}<0.05)$, the other two significant interactions were both negative: Finance with melting pot index $(-0.16$, $\mathrm{p}<0.05)$ and Public with melting pot index $(-0.34, \mathrm{p}<0.1)$. The interaction term of special

\footnotetext{
${ }^{8}$ Results suppressed in Tables 4 and 5 to save space.
} 
interest, Culture with melting pot index, was not statistically significant. Although a melting pot environment has been found important for innovation and growth in other studies (Florida, 2002; Audretsch et al. 2010; Boschma and Fritsch, 2009), our findings indicate that the relationship between creativity and economic development is not conditional upon a melting pot environment.

We now turn to our findings testing the creativity spillover of entrepreneurship: H2a predicted that entrepreneurship moderates the relationship between creativity and urban economic development. Several models in Table 4 provide support for H2a. A greater proportion employed in high-tech Manufacturing $(0.11, \mathrm{p}<0.1)$ and in Trade and hospitality $(0.14, \mathrm{p}<0.1)$ have a positive and statistically significant association with urban economic development, reported in Models 5 and 6 of Table 4, respectively. The same is true for a greater proportion employed in ICT $(0.01, \mathrm{p}<0.05)$ and Culture $(0.02, \mathrm{p}<0.05)$ sectors, shown in Models 9 and 10 of Table 4, respectively. Conditional upon higher entrepreneurship rates, a greater proportion employed in these sectors which are rich in creativity in production is positively and significantly associated with urban economic development. Interestingly, as shown in Model 7 of Table 4, Finance has a direct impact $(3.08 ; \mathrm{p}<0.05)$ but an insignificant incremental effect for urban economic development. It is noteworthy that a higher proportion of employed in the Culture sector, also known as Bohemians (Florida, 2002) is associated with greater urban economic development. Entrepreneurship is associated with opportunity recognition and bringing those opportunities to the market by launching a new business (Audretsch and Keilbach, 2007; Acs et al., 2009). Our findings support the idea that creativity embodied in people in industries does not per se result in economic development; rather, it is a combination of new business start-ups which commercialize the creativity in industries which is important for urban economic development. 
$\mathrm{H} 2 \mathrm{~b}$ predicted that the size of the creativity filter (the gap between real and potential creativity commercialization) would be larger with less entrepreneurship. We find support for $\mathrm{H} 2 \mathrm{~b}$ in Table 4, which shows that higher employment in four creative sectors, conditional on higher entrepreneurship, is associated with higher urban economic development: high-tech manufacturing shown in Model $5(0.11, \mathrm{p}<0.1)$, Trade and hospitality shown in Model 6 $(0.14, \mathrm{p}<0.1)$, ICT shown in Model $9(0.01, \mathrm{p}<0.05)$, and Culture $(0.02, \mathrm{p}<0.05)$ shown in Model 10. Our findings indicate that entrepreneur serves to minimize the size of the creativity filter. New start-ups can be seen as a process of formalization of new ideas, innovation and creativity (Audretsch and Lehmann, 2005). Our findings indicate that creative workers in the high-tech Manufacturing, Trade and hospitality, ICT and Culture sectors have more skills and knowledge, but entrepreneurial action is needed to spill this knowledge and creativity further. Creativity this way becomes economic knowledge (Arrow, 1962; Audretsch and Feldman, 1996), and the type of special market knowledge necessary to exploit opportunities is what entrepreneurs bring to the sector (Audretsch et al., 2006). Entrepreneurship thus acts as a conduit for creativity commercialization, and supports individuals to overcome the uncertainty related to market commercialization of ideas, and spill over creative ideas into new products (Audretsch and Belitski, 2013). In doing so, entrepreneurs decrease the creativity filter.

Additionally, more opportunities for idea exchange may be present in the melting pot environment. As a result of sharing ideas, there is a greater likelihood of experimentation and spinning off unique approaches to work (Pinto et al., 1993; Gilson and Shalley, 2004). We predicted in $\mathrm{H} 3$ that a melting pot environment would result in higher urban economic development. The results reported in Table 4 and 5 clearly provide support for H3: The coefficients of the melting pot environment (measured as non-EEU residents) remains statistically significant and positive across all specifications. In Table 4, this coefficient for 
melting pot environment was consistent for Models 2-4 and 7-11 $(0.04, \mathrm{p}<0.1)$ and consistent for Models 5-6 $(0.03, \mathrm{p}<0.1)$. The coefficient stayed positive and statistically significant in Table 5, but varied more across models: Models 2-4 (0.04, $\mathrm{p}<0.1)$, Model $5(0.02, \mathrm{p}<0.05)$, Model 6, 10, $11(0.05, \mathrm{p}<.01)$, Model 7 (0.07, $\mathrm{p}<0.1)$, Model $8(0.14, \mathrm{p}<0.1)$, and Model 9 $(0.06, \mathrm{p}<0.1)$. Overall, our results indicate the diversity and vibrancy (Stein, 1974) which accompanies a melting pot environment (Florida, 2002) boost urban economic development. This could be through letting people feel comfortable with their creative ideas and share their “idea mix" (Audretsch et al., 2010).

\section{Robustness check}

Economic areas which surpass, to varying degrees, administrative boundaries may impact economic development within a core city. Exogenous effects could bias the model as a dependent variable or could be subjected to distortion. LAUs limited by core city boundaries may not capture economic activity localized in larger urban zones (Eurostat, 2012). As pointed out by Cheshire and Magrini (2009), GDP is estimated at workplaces whereas people are counted where they live. To check for this possibility, a control was designed to compare two agglomeration economies: Within and outside the LAUs, based on the "market potential" approach (Harris, 1954).

The market potential $\mathrm{P}$ equals the sum of accessible market sizes (M), divided by the geographic distances to those markets (D). Cities can be seen as agglomerations of markets in a given area. Following Head and Mayer (2000), the sum of distances may be approximated as an area (A). By this, we assume that producers and consumers are evenly distributed within the area (A), which may not be the case. However, our objective is to capture the differences in magnitude of two levels of agglomeration economies: Within the core city and outside city boundaries. Market size potential (Harris, 1954) can be proxied by population 
size (number of city residents) living within certain agglomeration boundaries. We refer to this proxy as population density.

To perform a robustness check and access differences in economic activity which may exist between different spatial units, we compared two different densities, i.e., the core-city (LAU level 2) and larger urban zone (LUZ). LAU population density is related to LUZ population density with the following ratio $\frac{D_{L A U}}{D_{L U Z}}$. This control, demonstrating the difference between LAU and LUZ market potentials, was added to Model 11 in both Tables. The results are reported show the value of the coefficient is not statistically significant. Notably, factor coefficients for other explanatory variables have not changed their sign of significance, remaining similar to Model 10. Post-estimation Wald test did not yield evidence to support the significant bias in model estimation due to variations in the market potential across LUZ and LAU. In other words, our market potential Harris-type control has indicated neither the effect from larger urban zone externalities upon core-city economic performance, nor a distortion in the previously estimated effects.

We identified several city-outliers with a relatively high level of entrepreneurship. The top 5\% of the sample includes 9 cities with 3.5 times more than the mean value of entrepreneurship (39-47\%). In order to check the robustness of our model estimation, we excluded eight German cities (Berlin, Dortmund, Frankfurt-Oder, Halle an der Saale, Koln, Leipzig, Monchengladbach and Weimar) and one Spanish city (Murcia) from our sample as outliers and re-ran the estimations. Results on the main coefficients of interest in Tables 4 and 5 remained unchanged but the sample size fell to 178 cities.

\section{Discussion}

Three results are especially noteworthy. First, we found a positive direct impact of creativity embodied in the Culture sector on urban economic development, controlling for 
human capital (Glaeser et al., 2014). Although we did not find support for a combination of creativity and a melting pot effect to be positively associated with regional economic development, a melting pot environment on its own was found important (Florida 2002; Audretsch et al., 2010).

Second, we can conclude that creativity is not a magic bullet for urban economic development, and that a conduit is needed to commercialize creative ideas (Audretsch and Belitski, 2013). Not surprisingly, our results provided positive evidence that workers in four key sectors (high-tech Manufacturing, Trade and hospitality, ICT and Culture) are more likely to commercialize their creativity, unlike workers employed in other sectors. This could be attributed to a greater need for creativity in the basic functioning and productive activities in these sectors. Third, we confirmed that entrepreneurship is a catalyst for promoting urban economic development and spilling over creativity embedded in industries to the market. Entrepreneurship can be an important condition to commercialize creativity in cities where localized knowledge spillovers are most efficient (Arrow, 1962; Audretsch and Feldman, 1996; Glaeser et al., 2014; Audretsch et al., 2015). Entrepreneurship reduces the size of the creativity filter, in particular in the four sectors where creativity is likely part of a production process. Policymakers and company managers looking for ways to engage workers in creative activities (Drazin et al., 1999; Shalley et al., 2004; Shalley et al., 2009) should be aware of a conduit role of entrepreneurship in this process (Audretsch et al., 2006, 2008, 2010).

Our findings have interesting implications for entrepreneurs and corporate managers. First, entrepreneurs and managers may find that locating in melting pot environments provides not only better access to high quality potential employees, but also that potential spillovers can result from talent employed in other firms and sectors in a melting pot area. Second, entrepreneurial firms may benefit from interacting with creative workers, especially 
in the four sectors mentioned earlier, as this may provide greater access to new ideas. It may be worthwhile for entrepreneurs or managers to seek opportunities to engage with creative workers.

Overall, our findings lead to four interesting implications for local economic development policymakers. First, a melting pot environment could be an important tool in providing individuals with tolerance and diversity (Florida, 2002). If workers are exposed to creative abilities and appreciate diversity, they may engage in more intense collaborative networking. A melting pot environment could facilitate interactions between people and hence potentially increase the welfare of cities (Glaeser, 2004) as well as support their creative performance (Madjar et al., 2002). A supportive environment of this nature could serve a broader policy objective. Second, the exchange of ideas between the creative class and entrepreneurs is important for recognition, modification and exploitation of new ideas (Audretsch et. al., 2006). Entrepreneurs serve as a conduit for creative industries that result in commercialization of new ideas and therefore higher urban economic development. Identifying and supporting greater opportunities for interaction between entrepreneurs and creative workers could be an interesting approach for policymakers. Third, the existing complementarity of creativity embodied in workers and entrepreneurship may have both direct and indirect impacts on economic development in various sectors. This suggests it may be wide to consider the effects of policies on both workers and entrepreneurs. Fourth, we advise policymakers to consider supporting industry mix in such a way that promotes urban economic development, such as by supporting sectors with greater integration of creativity in productive activities.

\section{Concluding remarks}


Our study is the first to examine the concept of a creativity filter and creativity spillover of entrepreneurship. We propose the creativity spillover of entrepreneurship to better understand how creativity spills over for economic development (Audretsch et al., 2006; Agarwal et al., 2007, 2010). We examined creativity and urban economic development, with consideration of moderating roles for entrepreneurship and a melting pot environment. We use interaction analysis methodology (Brambor et al., 2006) to uncover complex, novel findings on creativity, melting pot environment, entrepreneurship and urban economic development. Using a panel from 187 European cities over the period 1999-2009, we present evidence on the existence, size and interacting dynamics of a creativity filter. We find that creativity contributes to urban economic development directly and indirectly through entrepreneurship. We also find evidence of the importance of a melting pot environment. Our findings show that the impact of creativity on urban economic development can actually be accelerated to generate creativity spillovers and minimize the creativity filter.

Our study lays the groundwork for further research moving towards a creativity theory spillover of entrepreneurship theory. Future research should attempt to identify and test a range of potential conduits for creativity to lead to urban economic development. We addresses a lack of city-level research which can shed light on how better to enable creativity spillover to help regional economic development (Lorenzen and Andersen, 2009; Marrocu and Paci, 2012; Audretsch et al., 2015). Few efforts have attempted to understand the mechanisms which spillover knowledge and creativity, in particular in cities, where interactions between the creative classes take place (Florida et al., 2008; Audretsch and Keilbach, 2007; Boschma and Fritsch, 2009).

Our contribution to the entrepreneurship literature is in marrying the knowledge spillover of entrepreneurship theory (Audretsch and Lehmann 2005; Audretsch and Keilbach 2007; Acs et al., 2009; Qian et al., 2012) with the burgeoning research on creativity and 
entrepreneurship (Florida, 2002; Florida et al., 2008; Florida and Mellander, 2010; Marrocu and Paci, 2012). We also make linkages with the organizational creativity literature (Amabile, 1996; Shalley Gilson and Blum, 2000; Shalley et al., 2004; Fleming and Marx, 2006; Shalley et al., 2009), an area which is ripe for deeper applications with entrepreneurship research.

\section{References}

Acs, Z.J., and Armington, C. 2006. Entrepreneurship, Agglomeration and US Regional Growth. Cambridge: Cambridge University Press.

Acs, Z.J., Audretsch, D.B., Braunerhjelm, P., Carlsson, B. 2009. The knowledge spillover theory of entrepreneurship. Small Business Economics, 32: 15-30.

Acs, Z. J., Autio, E., Szerb, L. 2014. National Systems of Entrepreneurship: Measurement Issues and Policy Implications. Research Policy, 43: 476-449.

Agarwal, R., Audretsch, D.B, Sarkar, M. 2007. The Process of Creative Construction: Knowledge Spillovers, Entrepreneurship and Economic Growth. Strategic Entrepreneurship Journal, 1: 263-286.

Agarwal, R., Audretsch, D.B, Sarkar, M. 2010. Knowledge Spillovers and Strategic Entrepreneurship. Strategic Entrepreneurship Journal, 4: 271-283.

Amabile, T. M. 1996. Creativity in context. Boulder, CO: Westview.

Arrow, K. 1962. Economic welfare and the allocation of resources for invention. In R. Nelson (Eds.), The rate and direction of inventive activity. NJ: Princeton University Press and NBER.

Asheim, B., and Hansen, H. K. 2009. Knowledge bases, talents, and contexts: On the usefulness of the creative class approach in Sweden. Economic Geography 85:425-42.

Audretsch, D. B., and Feldman, M. P. 1996. RandD spillovers and the geography of innovation and production. The American economic review 86: 630-640.

Audretsch, D.B and Lehmann, E.E. 2005. Does the knowledge spillover theory of entrepreneurship hold for regions? Research Policy, 34(8): 1191-1202.

Audretsch, D.B., Keilbach, M., and Lehmann, E., 2006. Entrepreneurship and economic growth. New York : Oxford University Press.

Audretsch, D.B., and Keilbach, M.C. 2007. The Theory of Knowledge Spillover Entrepreneurship. Journal of Management Studies, 44: 1242-1254.

Audretsch, D.B., Bönte, W., and Keilbach, M. 2008. Entrepreneurship capital and its impact on knowledge diffusion and economic performance. Journal of Business Venturing, 23: 687698.

Audretsch, D. B., Dohse, D., Niebuhr, A. 2010. Cultural diversity and entrepreneurship: a regional analysis for Germany. Annals of Regional Science, 45: 55-85.

Audretsch, D.B., and Belitski, M. 2013. The missing pillar: the creativity theory of knowledge spillover entrepreneurship. Small Business Economics, 41: 819-836.

Audretsch, D., Belitski, M., Desai, S. 2015. Entrepreneurship and Economic Development in Cities. Annals of Regional Sciences, Special Issue The Geography of Innovation" doi: 10.1007/s00168-015-0685-X

Bassett-Jones, N. (2005). The paradox of diversity management, creativity and innovation. Creativity and innovation management, 14(2), 169-175.

Baumol, W.J. 1993. Formal entrepreneurship theory in economics: existence and bounds. 
Journal of Business Venturing, 8: 197-210.

Boschma, R., and Fritsch, M. 2009. Creative Class and Regional Growth: Empirical Evidence from Seven European Countries. Economic Geography, 85: 391-423.

Brambor, T., Clark, W.R., and Golder, M. 2006. Understanding interaction models: improving empirical analyses, Political Analysis, 14: 63-82.

Brunello, G., and De Paola, M. 2004. Market failures and the under-provision of training. CES info paper. Business Innovation Department. 2010. Skills for Growth: The national skills strategy. BIS Economic paper No 4.

Cheshire, P., and Magrini, S. 2009. Urban growth drivers in a Europe of sticky people and implicit boundaries. Journal of Economic Geography, 9: 85-115.

Choi, J. N., Anderson, T. A., and Veillette, A. 2009. Contextual inhibitors of employee creativity in organizations: The insulating role of creative ability. Group and Organization Management, 34: 330-357.

Cohen, S. G., and Bailey, D. E. 1997. What makes teams work: Group effectiveness research from the shop floor to the executive suite. Journal of Management, 23: 239-290.

Douglas, P.H. 1976. The Cobb-Douglas production function once again: its history, its testing, and some new empirical values. Journal of Political Economy, 84: 903-915.

Drazin, R., Glynn, M. A., and Kazanjian, R. K. 1999. Multilevel theorizing about creativity in organizations: A sensemaking perspective. Academy of Management Review, 24: 286-307.

European Commission, 2010. European Regional and Urban Statistics Reference Guide. Eurostat Methodologies and Working Papers.

Eurostat 2012. City statistics - Urban audit. Accessed online in December 2nd, 2012 at: http://epp.eurostat.ec.europa.eu/portal/page/portal/region_cities/city_urban.

Falck, O., Fritsch., M., and Heblich, S. 2011. The Phantom of the Opera: Cultural Amenities, Human Capital, and Regional Economic Growth. IZA Discussion Paper No. 5065.

Fleming, L. and Marx, M. 2006. Managing Creativity in a Small World. California Management Review, 48: 6-27.

Fleming, L., Chen, D., and Mingo, S. 2007. Collaborative Brokerage, Generative Creativity, and Creative Success. Administration Science Quarterly, 52: 443-475.

Florida, R.L. 2002. The rise of the creative class. New York: Basic Books.

Florida, R., and Mellander, C. 2010. There Goes the Metro: How and Why Artists, Bohemians and Gays Effect Housing Values. Journal of Economic Geography, 10: 167-188.

Florida, R., Mellander, C., and Stolarick, K. 2008. Inside the black box of regional development: Human capital, the creative class and tolerance. Journal of Economic Geography, 8: 615-649.

Florida, R. 2012. The Connection Between Creativity and Entrepreneurship. Accessed online at http://www.theatlanticcities.com/jobs-and-economy/2012/08/creativity-entrepreneurshipconnection $/ 2847$

Gilson, L.L., and Shalley, C.E. 2004. A Little Creativity Goes a Long Way: An Examination of Teams' Engagement in Creative Processes. Journal of Management, 30(4): 453-470.

Glaeser, E.L. 2004. Review of Richard Florida's The rise of the creative class. Regional Science and Urban Economics, 35: 593-596.

Glaeser, E.L., Rosenthal S.S., Strange W.C. 2010. Urban economics and entrepreneurship. Journal of Urban Economics, 67: 1-14.

Glaeser, E.L., Ponzetto, G., Tobio, K. 2014. Cities, Skills and Regional Change. Regional Studies, 48: 7-43.

Harris, C.D. 1954. The market as a factor in the localization of industry in the United States, Annals of the Association of American Geographers, 44: 315-348.

Head, K., and Mayer, T. 2000. Non-Europe: The magnitude and causes of market fragmentation in the EU. Weltwirtschaftliches Archiv, 136: 284-314. 
Jovanovic, B., MacDonald, G.M., 1994. Competitive diffusion. The Journal of Political Economy 102 (1), 24-53.

Kahn, W. A. 1990. Psychological conditions of personally engagement and disengagement at work. Academy of Management Journal, 33: 692-724.

Lee, S.Y., Florida, R.L., and Acs, Z.J. 2004. Creativity and entrepreneurship: A regional analysis of new firm formation. Regional Studies, 38: 879-891.

Lorenzen, M., and Andersen, K. V. 2009. Centrality and creativity: Does Richard Florida's creative class offer new insights into urban hierarchy? Economic Geography 85:363-90.

Madjar, N., Oldham, G. R., and Pratt, M. G. 2002. There's no place like home? The contribution of work and nonwork creativity support to employees' creative performance. Academy of Management Journal, 45: 757-765.

Markusen, A. 2006. Urban development and the politics of a creative class: Evidence from the study of artists. Environment and Planning A 38:1921-40.

Marrocu, E. and Paci, R. 2012. Education or Creativity: What Matters Most for Economic Performance? Economic Geography, 88(4): 369-401

Marlet, G., and van Woerkens, C. 2004. Skills and creativity in a cross-section of Dutch cities. Koopmans Research Institute: Discussion Paper Series 04-29.

Oldham, G. R., and Cummings, A. 1996. Employee creativity: Personal and contextual factors at work. Academy of Management Journal, 39: 607-634.

Peri, G. 2005. Determinants of knowledge flows and their effect on innovation. Review of Economics and Statistics 87: 308-322.

Pinto, M. B., Pinto, J. K., and Prescott, J. E. 1993. Antecedents and consequences of project team cross-functional cooperation. Management Science, 39: 1281-1297.

Praag, C., and Versloot, P. 2007. What is the value of entrepreneurship? A review of recent research. Small Business Economics, 29: 351-382.

Preacher, K.J., Rucker, D.D., and Hayes, A.F. 2007. Addressing moderated mediation hypotheses: Theory, methods, and prescriptions. Multivariate Behavioral Research, 42: 185227.

Qian, H., Acs, Z.L., Stough, R. 2013. Regional systems of entrepreneurship: the nexus of human capital, knowledge and new firm formation. Journal of Economic Geography, 13: 559-587.

Rodríguez-Pose, A., and Vilalta-Bufì, M. 2005. Education, migration, and job satisfaction: The regional returns of human capital in the EU. Journal of Economic Geography 5:545-66.

Shalley, C.E., Zhou, J., and Oldham, G.R. 2004. The Effects of Personal and Contextual Characteristics on Creativity: Where Should We Go from Here? Journal of Management, 30(6): 933-958

Shalley, C. E., Gilson, L. L., and Blum, T. C. 2000. Matching creativity requirements and the work environment: Effects on satisfaction and intent to turnover. Academy of Management Journal, 43: 215-224.

Shalley, C. E., Gilson, L. L., and Blum, T. C. 2009. Interactive effects of growth need strength, work context, and job complexity on self-reported creative performance. Academy of Management Journal, 52: 489-505.

Shane, S., and Venkataraman, S. 2000. The promise of entrepreneurship as a field of research. Academy of Management Review, 25: 217-226.

Shin, S. J., and Zhou, J. 2003. Transformational leadership, conservation, and creativity: Evidence from Korea. Academy of Management Journal, 46: 703-714.

Sianesi, B. and Van Reenen, J. 2003. The Returns to Education: Macroeconomics, Journal of Economic Surveys, 17: 157-200. 
Somech, A., and Drach-Zahavy, A. 2013. Translating team creativity to innovation implementation the role of team composition and climate for innovation. Journal of Management, 39(3): 684-708.

Stein, M. K. 1974. Stimulating creativity. New York: Academic Press.

West, M. A. 1990. The social psychology of innovation in groups. In M. A. West and J. L. Farr (Eds.), Innovation and creativity at work: Psychological and organizational strategies: 555-576. Chichester: Wiley.

Zahra, S. A., and Wright, M. 2011. Entrepreneurship's next act. The Academy of Management Perspectives, 25(4): 67-83. 
FIGURE 1: Creativity Spillover of Entrepreneurship

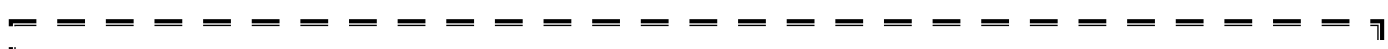

|| Creativity spillover of entrepreneurship (creativity filter)

II

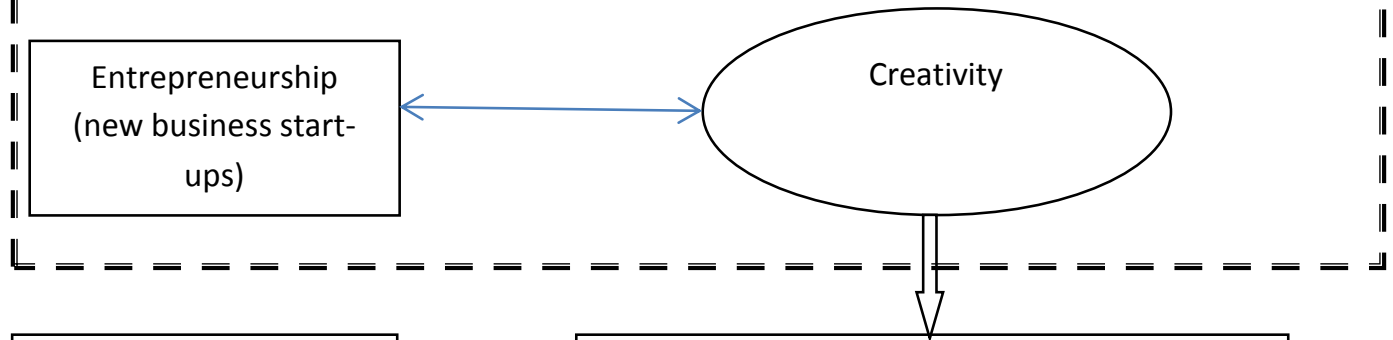

Melting pot environment (Diversity, openness, tolerance, institutions)

Economic development

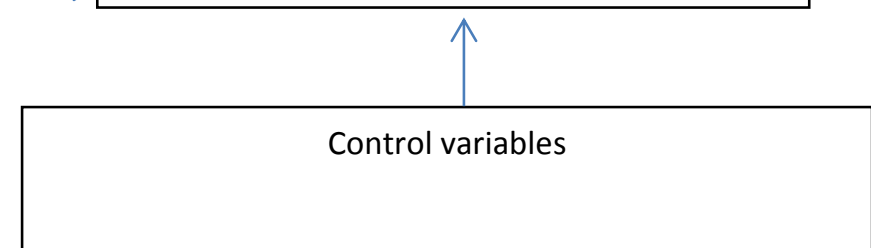


TABLE 1: Cities included in the study

\begin{tabular}{|c|c|}
\hline City & Country \\
\hline Brussels & Belgium \\
\hline \multicolumn{2}{|l|}{ Ruse, Plovdiv, Burgas, Pleven, Varna, Sofia, Vidin } \\
\hline Lefkosia & Cyprus \\
\hline $\begin{array}{l}\text { Frankfurt am Main, Trier, Augsburg, Potsdam, Bonn, Wiesbaden, Mainz, Freiburg im Breisgau, } \\
\text { Koblenz, Magdeburg, Weimar, Frankfurt-Oder, Erfurt, Dresden, Monchengladbach, Rostock, } \\
\text { Darmstadt, Dusseldorf, Moers, Halle an der Saale, Hannover, Karlsruhe, Bochum, Schwerin, Leipzig, } \\
\text { Bielefeld, Berlin, Regensburg, Munchen, Essen, Mulheim ad Ruhr, Koln, Kiel, Dortmund, Hamburg, } \\
\text { Nurnberg, Stuttgart, Saarbrucken, Bremen }\end{array}$ & Germany \\
\hline Tallinn, Tartu & Estonia \\
\hline $\begin{array}{c}\text { Cordoba, Las Palmas, Gijon, Zaragoza, Santiago de Compostela, Badajoz, Malaga, Santander, } \\
\text { Hospitalet de Llobregat, Vitoria/Gasteiz, Valladolid, Toledo, Sevilla, Murcia, Vigo, Oviedo, Sta. Cruz } \\
\text { de Tenerife, Pamplona/Iruna, Bilbao, Madrid, Barcelona, Valencia, Logrono, Alicante/Alacant }\end{array}$ & Spain \\
\hline Kernel Helsinki, Helsinki, Tampere, Turku, Oulu & Finland \\
\hline $\begin{array}{l}\text { Lens - Lievin, Tours, Rouen, Amiens, Ajaccio, Nantes, Paris, Metz, Marseille, Nancy, Orleans, Dijon, } \\
\text { Le Havre, Grenoble, Poitiers, Strasbourg, Saint-Etienne, Montpellier, Limoges, Caen, Besancon, Saint } \\
\text { Denis, Aix-en-Provence, Toulouse, Bordeaux, Lyon, Lille, Reims, Clermont-Ferrand }\end{array}$ & France \\
\hline Budapest Debrecen Gyor Kecskemet Miskolc, Nyiregyhaza Pecs Szeged Szekesfehervar & Hungary \\
\hline Panevezys, Kaunas, Vilnius & Lithuania \\
\hline $\begin{array}{l}\text { Ancona, Catanzaro, Venezia, Genova, Taranto, Perugia, Aquila, Potenza, Catania, Caserta, Cagliari, } \\
\text { Foggia, Sassari, Verona, Bari, Roma, Salerno, Firenze, Milano, Brescia, Trieste, Napoli, Modena, } \\
\text { Trento, Palermo, Reggio di Calabria, Bologna, Torino, Padova, Campobasso, Cremona, Pescara }\end{array}$ & Italy \\
\hline Riga, Liepaja & Latvia \\
\hline $\begin{array}{l}\text { Almere, Breda, Arnhem, Apeldoorn, Amsterdam, Eindhoven, Tilburg, s-Gravenhage, Groningen, } \\
\text { Leeuwarden, Rotterdam, Enschede, Heerlen Nijmegen, Utrecht }\end{array}$ & Netherlands \\
\hline Goteborg, Linkoping, Malmo, Orebro, Stockholm, Umea, Jonkoping & Sweden \\
\hline Maribor, Ljubljana & Slovenia \\
\hline Kosice, Banska Bystrica, Nitra, Presov, Zilina, Trnava, Bratislava, Trencin & Slovakia \\
\hline
\end{tabular}

Source: Eurostat (2012): Urban and regional statistics 1994-2009. 
FIGURE 2: Cities included in the study

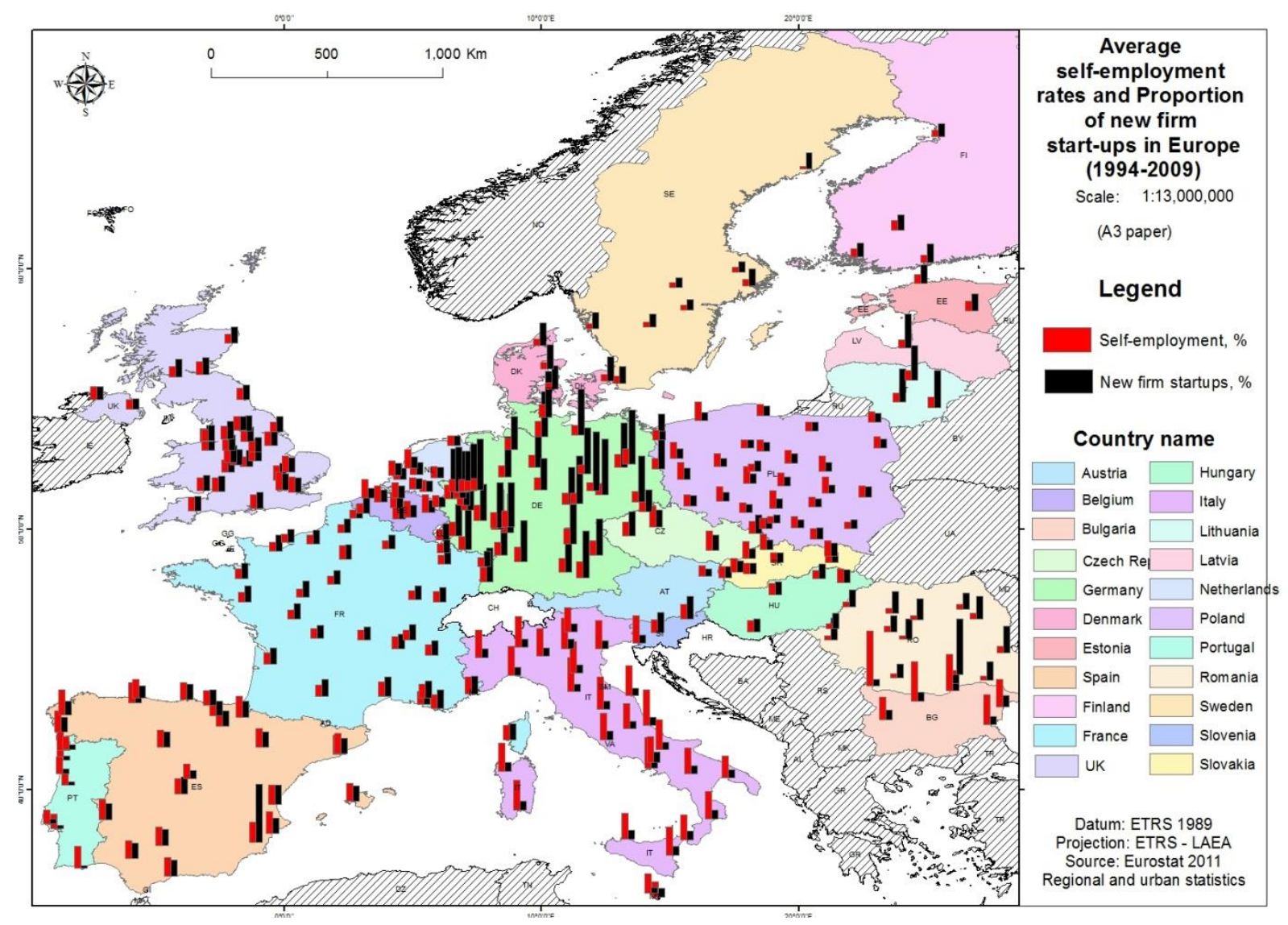

Source: Authors calculations based on Eurostat (2012) 
TABLE 2: VARIABLES AND SUMMARY STATISTICS

\begin{tabular}{|c|c|c|c|c|c|}
\hline Variables & Definition & Mean & St. dev. & Min & Max \\
\hline GDP & Gross Domestic Product in PPP prices, logarithm & 10.07 & 0.49 & 8.58 & 11.16 \\
\hline $\begin{array}{l}\text { High-tech } \\
\text { manufacturing }\end{array}$ & $\begin{array}{l}\text { Proportion employed in high-tech manufacturing } \\
\text { industry }\end{array}$ & 0.13 & 0.06 & 0.03 & 0.36 \\
\hline $\begin{array}{l}\text { Trade and } \\
\text { hospitality }\end{array}$ & $\begin{array}{l}\text { Proportion of employment in trade, hotels } \\
\text { restaurants and other food industry }\end{array}$ & 0.15 & 0.04 & 0.05 & 0.26 \\
\hline Finance & $\begin{array}{l}\text { Proportion of employment in financial } \\
\text { intermediation and business activities }\end{array}$ & 0.16 & 0.08 & 0.02 & 0.51 \\
\hline Public & $\begin{array}{l}\text { Proportion of employment in public administration, } \\
\text { health and education industry }\end{array}$ & 0.28 & 0.08 & 0.14 & 0.53 \\
\hline ICT & $\begin{array}{c}\text { Proportion of employed in manufacturing ICT } \\
\text { products and content }\end{array}$ & 10.13 & 7.79 & 0.90 & 82.70 \\
\hline Culture & $\begin{array}{c}\text { Proportion of employment in culture and } \\
\text { entertainment industry }\end{array}$ & 2.58 & 3.29 & 0.10 & 33.90 \\
\hline Entrepreneurship & $\begin{array}{l}\text { New businesses registered in proportion of existing } \\
\text { companies }\end{array}$ & 21.30 & 13.11 & 0.40 & 56.90 \\
\hline Population density & Population density & 1866.23 & 2063.07 & 44.20 & 20248.2 \\
\hline Human Capital & $\begin{array}{l}\text { Proportion of residents with tertiary education } \\
\text { (ISCED 5-6) }\end{array}$ & 23.66 & 6.90 & 6.00 & 41.80 \\
\hline Melting Pot Index & $\begin{array}{c}\text { Non-EEA nationals as a proportion of total } \\
\text { population }\end{array}$ & 6.08 & 4.25 & 0.19 & 16.22 \\
\hline Market potential & $\begin{array}{l}\text { Ratio of local administrative unit population density } \\
\text { (LAU) to larger urban zone population density, } \\
\text { 1994-2009 averaged (Harris 1954) }\end{array}$ & 12.94 & 36.38 & 0.80 & 354.54 \\
\hline
\end{tabular}

Source: Author calculations based on Eurostat (2012)

Note: Interaction variables which are the product of entrepreneurship and proportion of employment by sector are supressed here to save space. The total number of cities is 187 and total number of observations is 240 . 
TABLE 3: Correlation matrix

\begin{tabular}{|c|c|c|c|c|c|c|c|c|c|c|}
\hline & 1 & 2 & 3 & 4 & 5 & 6 & 7 & 8 & 9 & 10 \\
\hline 1. GDP & 1.00 & & & & & & & & & \\
\hline $\begin{array}{l}\text { 2. High-tech } \\
\text { manufacturing }\end{array}$ & 0.05 & 1.00 & & & & & & & & \\
\hline 3. Trade and hospitality & $0.48 *$ & $0.45 *$ & 1.00 & & & & & & & \\
\hline 4. Finance & $0.76^{*}$ & 0.06 & $0.61 *$ & 1.00 & & & & & & \\
\hline 5. Public & $0.51 *$ & -0.10 & $0.31 *$ & $0.42 *$ & 1.00 & & & & & \\
\hline 6. ICT & $0.32 *$ & $0.13 *$ & $0.23 *$ & $0.32 *$ & 0.10 & 1.00 & & & & \\
\hline 7. Culture & 0.06 & -0.07 & 0.01 & 0.08 & $0.11 *$ & $0.53 *$ & 1.00 & & & \\
\hline 8. Entrepreneurship & $0.37 *$ & 0.00 & $0.25 *$ & $0.36 *$ & $0.19 *$ & 0.07 & -0.02 & 1.00 & & \\
\hline 9. Population density & $0.25 *$ & -0.04 & $0.18^{*}$ & $0.26^{*}$ & -0.04 & $0.19 *$ & 0.10 & 0.03 & 1.00 & \\
\hline 10. Human Capital & $0.19 *$ & $\begin{array}{c}- \\
0.27 * \\
\end{array}$ & $\begin{array}{c}- \\
0.12 *\end{array}$ & $0.12 *$ & $0.20 *$ & $0.29 *$ & $0.14^{*}$ & $\begin{array}{c}- \\
0.23^{*} \\
\end{array}$ & 0.00 & 1.00 \\
\hline 11. Melting Pot Index & $0.62 *$ & $0.17 *$ & $0.43 *$ & $0.60 *$ & $0.14 *$ & $0.23 *$ & 0.00 & $0.56 *$ & $0.36^{*}$ & ${ }^{-}$ \\
\hline
\end{tabular}

Note: Significance is 5\%.

Source: Eurostat (2012). 
TABLE 4: Results with entrepreneurship (dependent variable: GDP per capita in PPP, in logs)

\begin{tabular}{|c|c|c|c|c|c|c|c|c|c|c|c|}
\hline Model & (1) & (2) & (3) & (4) & (5) & (6) & (7) & (8) & (9) & (10) & (11) \\
\hline Manufacturing & $\begin{array}{c}0.38 \\
(0.42) \\
\end{array}$ & $\begin{array}{c}0.19 \\
(0.43) \\
\end{array}$ & $\begin{array}{c}0.19 \\
(0.43) \\
\end{array}$ & $\begin{array}{c}0.09 \\
(0.43) \\
\end{array}$ & $\begin{array}{c}-2.29 * * \\
(0.94)\end{array}$ & $\begin{array}{l}-0.19 \\
(0.48) \\
\end{array}$ & $\begin{array}{c}0.29 \\
(0.41) \\
\end{array}$ & $\begin{array}{c}0.54 \\
(0.34) \\
\end{array}$ & $\begin{array}{c}0.38 \\
(0.36) \\
\end{array}$ & $\begin{array}{c}0.18 \\
(0.38) \\
\end{array}$ & $\begin{array}{r}0.18 \\
(0.38 \\
\end{array}$ \\
\hline Trade and hospitality & $\begin{array}{c}-0.86 \\
(0.73) \\
\end{array}$ & $\begin{array}{c}-0.33 \\
(0.68) \\
\end{array}$ & $\begin{array}{c}-0.33 \\
(0.68) \\
\end{array}$ & $\begin{array}{c}0.40 \\
(1.78) \\
\end{array}$ & $\begin{array}{c}0.20 \\
(1.84) \\
\end{array}$ & $\begin{array}{c}-2.38 \\
(1.94) \\
\end{array}$ & $\begin{array}{c}0.12 \\
(1.71) \\
\end{array}$ & $\begin{array}{c}0.17 \\
(1.59) \\
\end{array}$ & $\begin{array}{c}0.12 \\
(1.73) \\
\end{array}$ & $\begin{array}{c}0.08 \\
(1.83) \\
\end{array}$ & $\begin{array}{r}0.08 \\
(1.83 \\
\end{array}$ \\
\hline Finance & $\begin{array}{c}3.84 * * * \\
(0.39)\end{array}$ & $\begin{array}{c}2.57 * * * \\
(0.37)\end{array}$ & $\begin{array}{c}2.57 * * * \\
(0.37)\end{array}$ & $\begin{array}{c}2.19 * * * \\
(0.50)\end{array}$ & $\begin{array}{c}2.20 * * * \\
(0.53)\end{array}$ & $\begin{array}{c}2.16 * * * \\
(0.53)\end{array}$ & $\begin{array}{c}3.08 * * \\
(1.16)\end{array}$ & $\begin{array}{c}2.09 * * * * \\
(0.48)\end{array}$ & $\begin{array}{c}2.28 * * * \\
(0.48)\end{array}$ & $\begin{array}{c}2.24 * * * \\
(0.52)\end{array}$ & $\begin{array}{r}2.24 * * \\
(0.52\end{array}$ \\
\hline Public & $\begin{array}{c}1.64 * * * \\
(0.27)\end{array}$ & $\begin{array}{c}1.75^{*} * * \\
(0.27)\end{array}$ & $\begin{array}{c}1.75 * * * \\
(0.27)\end{array}$ & $\begin{array}{c}1.80 * * * \\
(0.55)\end{array}$ & $\begin{array}{c}1.60 * * * \\
(0.50)\end{array}$ & $\begin{array}{c}1.74 * * * \\
(0.45)\end{array}$ & $\begin{array}{l}1.72 * * \\
(0.57)\end{array}$ & $\begin{array}{c}3.82 * * * * \\
(0.97)\end{array}$ & $\begin{array}{c}1.84 * * * \\
(0.57)\end{array}$ & $\begin{array}{c}1.91 * * * \\
(0.56)\end{array}$ & $\begin{array}{r}1.91 * * \\
(0.56\end{array}$ \\
\hline ICT & $\begin{array}{c}0.01 * * * \\
(0.00)\end{array}$ & $\begin{array}{c}0.00 \\
(0.00)\end{array}$ & $\begin{array}{c}0.00 \\
(0.00)\end{array}$ & $\begin{array}{c}0.01 \\
(0.01)\end{array}$ & $\begin{array}{c}0.01 \\
(0.01)\end{array}$ & $\begin{array}{c}0.01 \\
(0.01)\end{array}$ & $\begin{array}{c}0.01 \\
(0.01)\end{array}$ & $\begin{array}{c}0.01 \\
(0.01)\end{array}$ & $\begin{array}{c}0.03 * * \\
(0.01)\end{array}$ & $\begin{array}{c}0.01 \\
(0.01)\end{array}$ & $\begin{array}{r}0.01 \\
(0.01\end{array}$ \\
\hline Culture & & $\begin{array}{l}0.01 * \\
(0.00) \\
\end{array}$ & $\begin{array}{l}0.01 * \\
(0.00) \\
\end{array}$ & $\begin{array}{l}-0.00 \\
(0.01) \\
\end{array}$ & $\begin{array}{l}-0.00 \\
(0.01) \\
\end{array}$ & $\begin{array}{l}-0.00 \\
(0.01)\end{array}$ & $\begin{array}{l}-0.00 \\
(0.01) \\
\end{array}$ & $\begin{array}{l}-0.00 \\
(0.01) \\
\end{array}$ & $\begin{array}{l}-0.01 \\
(0.01) \\
\end{array}$ & $\begin{array}{l}0.04 * \\
(0.02) \\
\end{array}$ & $\begin{array}{l}0.04 \\
(0.02 \\
\end{array}$ \\
\hline Start-ups & $\begin{array}{c}0.01 * * * \\
(0.00)\end{array}$ & $\begin{array}{c}0.00 \\
(0.00) \\
\end{array}$ & $\begin{array}{c}0.00 \\
(0.00) \\
\end{array}$ & $\begin{array}{c}0.00 \\
(0.00) \\
\end{array}$ & $\begin{array}{c}0.01 * * \\
(0.00)\end{array}$ & $\begin{array}{l}0.02 * \\
(0.01)\end{array}$ & $\begin{array}{c}0.01 \\
(0.01) \\
\end{array}$ & $\begin{array}{c}0.02 * * \\
(0.01)\end{array}$ & $\begin{array}{l}0.01 * \\
(0.01)\end{array}$ & $\begin{array}{l}0.01 * \\
(0.00)\end{array}$ & $\begin{array}{l}0.01 \\
(0.00\end{array}$ \\
\hline Market size potential & & $\begin{array}{c}0.00 \\
(0.00) \\
\end{array}$ & $\begin{array}{c}0.00 \\
(0.00) \\
\end{array}$ & $\begin{array}{c}0.00 \\
(0.00) \\
\end{array}$ & $\begin{array}{c}0.00 \\
(0.00) \\
\end{array}$ & $\begin{array}{c}0.00 \\
(0.00) \\
\end{array}$ & $\begin{array}{c}0.00 \\
(0.00) \\
\end{array}$ & $\begin{array}{c}0.00 \\
(0.00) \\
\end{array}$ & $\begin{array}{c}0.00 \\
(0.00) \\
\end{array}$ & $\begin{array}{c}0.00 \\
(0.00) \\
\end{array}$ & $\begin{array}{r}0.00 \\
(0.00 \\
\end{array}$ \\
\hline Human Capital & & $\begin{array}{c}0.01 * * * \\
(0.00)\end{array}$ & $\begin{array}{c}0.01 * * * \\
(0.00)\end{array}$ & $\begin{array}{l}0.01 * * \\
(0.00)\end{array}$ & $\begin{array}{l}0.01 * * \\
(0.00)\end{array}$ & $\begin{array}{l}0.01 * * \\
(0.00)\end{array}$ & $\begin{array}{l}0.01 * * \\
(0.00)\end{array}$ & $\begin{array}{l}0.01 * * \\
(0.00)\end{array}$ & $\begin{array}{l}0.01 * * \\
(0.00)\end{array}$ & $\begin{array}{l}0.01 * * \\
(0.00)\end{array}$ & $\begin{array}{l}0.01 * \\
(0.00\end{array}$ \\
\hline Melting Pot & & $\begin{array}{c}0.04 * * * \\
(0.01)\end{array}$ & $\begin{array}{c}0.04 * * * \\
(0.01)\end{array}$ & $\begin{array}{c}0.04 * * * \\
(0.01)\end{array}$ & $\begin{array}{c}0.03 * * * \\
(0.01)\end{array}$ & $\begin{array}{c}0.03 * * * \\
(0.01)\end{array}$ & $\begin{array}{c}0.04 * * * \\
(0.01)\end{array}$ & $\begin{array}{c}0.04 * * * \\
(0.01)\end{array}$ & $\begin{array}{c}0.04 * * * \\
(0.01)\end{array}$ & $\begin{array}{c}0.04 * * * \\
(0.01)\end{array}$ & $\begin{array}{r}0.04 * * \\
(0.01 \\
\end{array}$ \\
\hline $\begin{array}{c}\text { Manufacturing } \mathrm{x} \\
\text { start-ups }\end{array}$ & & & & & $\begin{array}{c}0.11 * * * \\
(0.03)\end{array}$ & & & & & & \\
\hline $\begin{array}{c}\text { Trade and hospitality } \mathrm{x} \\
\text { start-ups }\end{array}$ & & & & & & $\begin{array}{c}0.14 * * * \\
(0.04)\end{array}$ & & & & & \\
\hline Finance x start-ups & & & & & & & $\begin{array}{l}-0.03 \\
(0.03)\end{array}$ & & & & \\
\hline Public x start-ups & & & & & & & & $\begin{array}{c}-0.08 * * \\
(0.03)\end{array}$ & & & \\
\hline ICT x start-ups & & & & & & & & & $\begin{array}{l}0.01 * * \\
(0.00)\end{array}$ & & \\
\hline Culture x start-ups & & & & & & & & & & $\begin{array}{c}0.02 * * \\
(0.00) \\
\end{array}$ & \\
\hline Harrison type index & & & & & & & & & & & $\begin{array}{l}-0.07 \\
(0.12\end{array}$ \\
\hline Constant & $\begin{array}{c}8.92 * * * \\
(0.09)\end{array}$ & $\begin{array}{c}8.74 * * * * \\
(0.13)\end{array}$ & $\begin{array}{c}8.74 * * * * \\
(0.13)\end{array}$ & $\begin{array}{c}8.45 * * * \\
(0.21)\end{array}$ & $\begin{array}{c}9.24 * * * \\
(0.21)\end{array}$ & $\begin{array}{c}9.28 * * * \\
(0.24) \\
\end{array}$ & $\begin{array}{c}8.79 * * * \\
(0.19)\end{array}$ & $\begin{array}{c}8.37 * * * \\
(0.30)\end{array}$ & $\begin{array}{c}8.75 * * * \\
(0.17)\end{array}$ & $\begin{array}{c}8.77 * * * \\
(0.17)\end{array}$ & $\begin{array}{r}8.78 \text { ** } \\
(0.17 \\
\end{array}$ \\
\hline Time dummies & No & Yes & Yes & Yes & Yes & Yes & Yes & Yes & Yes & Yes & Yes \\
\hline Country dummies & No & No & No & Yes & Yes & Yes & Yes & Yes & Yes & Yes & Yes \\
\hline Observations & 240 & 240 & 240 & 240 & 240 & 240 & 240 & 240 & 240 & 240 & 240 \\
\hline R-squared & 0.63 & 0.71 & 0.71 & 0.76 & 0.77 & 0.77 & 0.76 & 0.77 & 0.77 & 0.77 & 0.77 \\
\hline
\end{tabular}

Note: Level of statistical significance is $* * * \mathrm{p}<.10 * * \mathrm{p}<.05$ and $* \mathrm{p}<.01$. Standard errors clustered by country and robust for heteroskedasticity are in parenthesis. Country and time dummies are supressed to save space. Source: Authors calculations. 
TABLE 5: Results with melting pot environment (dependent variable: GDP per capita in PPP, in logs)

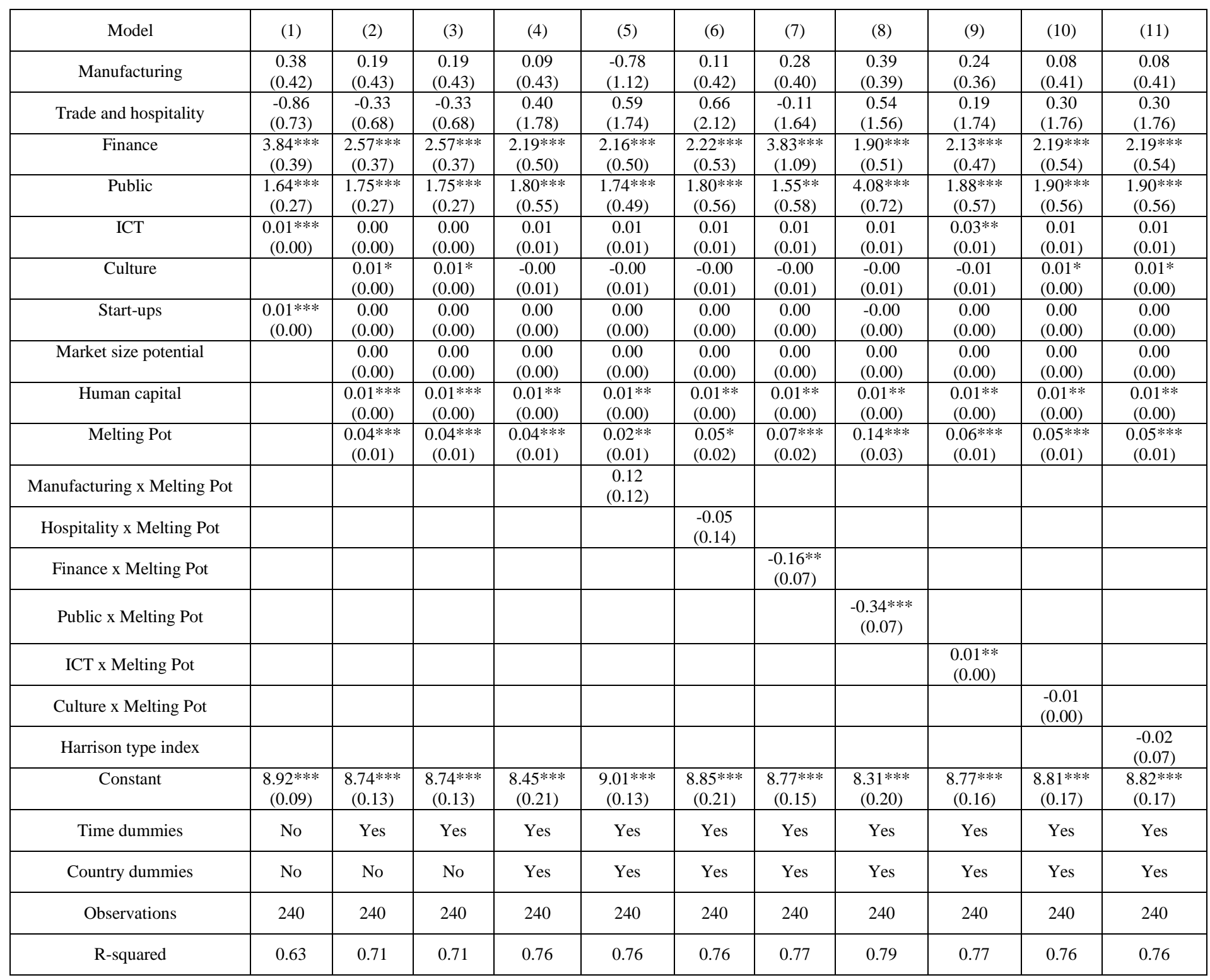

Note: Level of statistical significance is $* * * \mathrm{p}<.10 * * \mathrm{p}<.05$ and $* \mathrm{p}<.01$. Standard errors clustered by country and robust for heteroskedasticity are in parenthesis. Country and time dummies are supressed to save space. Source: Authors calculations. 